\title{
GMR
}

\section{Association between GSTM1, GSTT1, and GSTP1 polymorphisms and gastric cancer risk, and their interactions with environmental factors}

\author{
Z.H. Chen, J.F. Xian and L.P. Luo \\ The First Affiliated Hospital of Jinan University, Guangzhou, China \\ Corresponding author: L.P. Luo \\ E-mail: zuhuichen66@163.com \\ Genet. Mol. Res. 16 (1): gmr16018877 \\ Received July 13, 2016 \\ Accepted December 1, 2016 \\ Published February 8, 2017 \\ DOI http://dx.doi.org/10.4238/gmr16018877
}

Copyright $(C 2017$ The Authors. This is an open-access article distributed under the terms of the Creative Commons Attribution ShareAlike (CC BY-SA) 4.0 License.

\begin{abstract}
Glutathione S-transferase (GST) is an important member of phase II metabolic enzymes; GSTM1, GSTT1, and GSTP1 belong to three subfamilies of the GST enzyme. Polymorphisms in GSTM1, GSTT1, and GSTP1 could affect detoxification processes, and increase individuals' susceptibility to cancers. We aimed to investigate the association between GSTM1, GSTT1, and GSTP1 polymorphisms and the risk of gastric cancer in a Chinese population. In addition, we also examined the effect of gene-environmental interactions, and their effect on risk of this cancer. Between July 2013 and June 2015, we recruited 242 gastric cancer patients and 396 healthy controls for our study. Polymerase chain reaction-restriction fragment length polymorphism analysis was used to characterize genetic polymorphisms in GSTM1, GSTT1, and GSTP1. We observed that the Val/Val genotype of GSTP1 was associated with increased risk of gastric cancer when compared with the Ile/Ile genotype $(\mathrm{OR}=3.19,95 \% \mathrm{CI}=1.84-5.56)$. Moreover, the Val allele of GSTP 1 was associated with higher susceptibility to gastric cancer as compared with
\end{abstract}


the Ile allele $(\mathrm{OR}=1.52,95 \% \mathrm{CI}=1.19-1.93)$. However, GSTM1 and GSTT1 polymorphisms did not affect the development of gastric cancer. In conclusion, our study indicated that GSTP1 Ile105Val, but not GSTM1 and GSTT1 polymorphisms, was associated with risk of gastric cancer.

Key words: Glutathione S-transferase; Polymorphism; Gastric cancer; Environmental factors

\section{INTRODUCTION}

Gastric cancer is the fourth most commonly diagnosed cancer and is the second leading cause of cancer-related deaths worldwide (Farlay et al., 2013). It has been estimated that there are approximately 952,000 new gastric cancer cases per year with 405,000 cases in China alone (Farlay et al., 2013). Incidence of this disease varies across different populations, suggesting that environmental factors play an important role in its pathogenesis. Studies have shown that many environmental factors such as Helicobacter pylori infection, long-term smoking, longterm drinking, family history of cancer, high intake of pickled food, low intake of fruits and vegetables, and high salted diet contribute to the development of gastric cancer (Khayatzadeh et al., 2015; den Hoed and Kuipers, 2016; Lee et al., 2016; Zhang et al., 2016). However, not all individuals with associated risk factors develop gastric cancer, suggesting that genetic factors may also contribute to its pathogenesis. An increasing number of studies reported that genetic factors such as thrombospondin-2, thrombospondin-4, miR-146a, cytochrome P450 1A1, matrix metalloproteinases, interleukin- 8 , prostate stem cell antigen, and interleukin- 17 contribute to the development of gastric cancer (Li et al., 2015; Shi et al., 2015; Zhang et al., 2015; Hidaka et al., 2016; Lin et al., 2016; Okada et al., 2016; Qiu et al., 2016; Xia et al., 2016).

Furthermore, tar, nicotine, and carbon monoxide in cigarettes may also lead to the development of gastric cancer. These substances are first oxidized, restored, and hydrolyzed by phase I metabolic enzymes. The end-products are then metabolized by phase II metabolic enzymes and excreted out of the body. Glutathione S-transferase (GST) is an important member of phase II metabolic enzymes. GSTM1, GSTT1, and GSTP1 are members of three subfamilies of the GST enzyme. Deletion of the GSTM1 or GSTT1 genes and non-synonymous GSTP1 Ile105Val could affect the expression and activity of the enzymes, and thereby lead to impaired detoxification and cancers (Broekman et al., 2014; Rao et al., 2014; Guven et al., 2015). Previous studies have reported the association between GSTM1, GSTT1, and GSTP1 polymorphisms and gastric cancer (Tripathi et al., 2008; Nguyen et al., 2010; Yadav et al., 2010; Zhang et al., 2011; García-González et al., 2012) with inconsistent results. In addition, there are no reports about the interactions between GSTM1, GSTT1, and GSTP1 polymorphisms and smoking. In the present study, we aimed to investigate the association between GSTM1, GSTT1, and GSTP1 polymorphisms and risk of gastric cancer in a Chinese population. We also examined the effect of gene-environmental interactions on gastric cancer risk.

\section{MATERIAL AND METHODS}

\section{Subjects}

We recruited 242 gastric cancer patients and 396 healthy controls between July 2013

Genetics and Molecular Research 16 (1): gmr16018877 
and June 2015. Patients were recruited from the First Affiliated Hospital of Jinan University, and the disease was confirmed in all individuals by pathologists. Those who received any form of chemotherapy prior to enrollment were excluded from this study. Patients who had prior history of other malignant tumors, metastatic tumors, recurrent tumors, malnutrition, endstage liver, or kidney diseases were also excluded.

Controls were recruited from the hospital outpatient clinics and health examination centers. All the control subjects underwent digestive endoscopy examinations, and were confirmed to be free of gastric cancers, history of any other cancers, diseases of the digestive system, and end-stage liver or kidney diseases. Demographic information of all the participants were collected from medical records, and included gender, age, family history of cancer, smoking and drinking habits, as well as intake of pickled foods.

Written informed consents were obtained from all subjects prior to enrollment, and the study protocols were approved by the Ethics Committee of the First Affiliated Hospital of Jinan University.

\section{Genotyping analysis}

Prior to receiving any forms of treatment, blood samples were collected into EDTA tubes for total genomic DNA extraction. DNA extraction was performed using the DNA extraction kit (QIAGEN, Hilden, Germany), according to manufacturer instructions. PCRRFLP analysis was used to characterize genetic polymorphisms in GSTM1, GSTT1, and GSTP1. The forward and reverse primers for GSTM1 were 5'-GAACTCCCTGAAAAGCTAAAGC-3' and 5'-GTTGGGCTCAAATATACGGTGG-3', respectively. The forward and reverse primers for GSTT1 were 5'-TTCCTTACTGGTCCTCCACATCTC-3' and 5'-TCACCGGATCATGGC CAGCA-3', respectively. The forward and reverse primers for GSTP1 were 5'-GTAGTTTGC CCAAGGTCAAG-3' and 5'-AGCCACCTGAGGGGTAAG-3', respectively. The forward and reverse primers for the reference gene ( $\beta$-globulin) were 5'-CAACTCATCCACGTTCACC-3' and 5'-CAACTTCATCCACGTTCACC-3', respectively. The 50- $\mu \mathrm{L}$ PCR mixture contained $5 \mu \mathrm{L}$ 10X PCR buffer solution, $4 \mu \mathrm{L}$ dNTP $(2.5 \mathrm{mM}), 2 \mu \mathrm{L}$ forward and reverse primers $(10$ $\mathrm{mM}), 2.5 \mu \mathrm{L}$ TaqDNA polymerase, $2 \mu \mathrm{L}$ DNA template, and $37 \mu \mathrm{L}$ hydrogen peroxide. The cycling conditions for GSTT1 and GSTM1 were as follows: $95^{\circ} \mathrm{C}$ for $5 \mathrm{~min} ; 35$ cycles of $94^{\circ} \mathrm{C}$ for $45 \mathrm{~s}, 58^{\circ} \mathrm{C}$ for $40 \mathrm{~s}$, and $72^{\circ} \mathrm{C}$ for $50 \mathrm{~s}$; final extension at $72^{\circ} \mathrm{C}$ for $7 \mathrm{~min}$. The cycling parameters for GSTP1 were as follows: $95^{\circ} \mathrm{C}$ for $5 \mathrm{~min}$; 35 cycles of $94^{\circ} \mathrm{C}$ for $45 \mathrm{~s}, 62^{\circ} \mathrm{C}$ for $40 \mathrm{~s}$, and $72^{\circ} \mathrm{C}$ for $50 \mathrm{~s}$; final extension at $72^{\circ} \mathrm{C}$ for $7 \mathrm{~min}$. Amplified GSTT1 and GSTM1 fragments were ran on a $8 \%$ polyacrylamide gel. The PCR products of GSTP1 were digested by $B s m \mathrm{AI}$, and the DNA fragments were ran on a $12 \%$ polyacrylamide gel.

The PCR products of GSTM1, GSTT1, and $\beta$-globulin were 236, 480, and $268 \mathrm{bp}$, respectively. The Ile/Ile GSTP1 fragments were 329 and $113 \mathrm{bp}$, the Ile/Val fragments were 329 and $216 \mathrm{bp}$, and the Val/Val fragments were 216 and $113 \mathrm{bp}$.

\section{Statistical analysis}

Categorical variables were reported as percentages of the total. Pearson's chisquared and Fisher exact tests were used to determine inter-group differences. Departure from Hardy-Weinberg equilibrium (HWE) was also assessed by these tests. Multiple logistic regression analysis was carried out to evaluate the association between GSTM1,

Genetics and Molecular Research 16 (1): gmr16018877 
GSTT1, and GSTP1 polymorphisms and the risk of gastric cancer. Results were expressed using odds ratios (ORs) and 95\% confidence intervals (CIs). The wild-type genotype was used as the reference group. Interactions between GSTM1, GSTT1, and GSTP1 polymorphisms and smoking habits were analyzed using Spearman correlation analysis. P $<0.05$ was considered statistically significant.

\section{RESULTS}

The demographic and lifestyle characteristics of the subjects are presented in Table 1. According to chi-squared analysis, patients were more likely to be smokers $\left(\chi^{2}=4.82, \mathrm{P}=\right.$ $0.03)$ and have a family history of cancers $\left(\chi^{2}=7.16, \mathrm{P}=0.01\right)$ when compared to the controls. However, no significant difference was found between the two groups in age $\left(\chi^{2}=0.16, \mathrm{P}=\right.$ $0.69)$, gender $\left(\chi^{2}=0.49, \mathrm{P}=0.48\right)$, drinking status $\left(\chi^{2}=1.18, \mathrm{P}=0.28\right)$, and intake of pickled food $\left(\chi^{2}=1.97, \mathrm{P}=0.16\right)$.

Table 1. Demographic and lifestyle characteristics of the subjects.

\begin{tabular}{|c|c|c|c|c|c|c|}
\hline & Patients & $\%$ & Controls & $\%$ & $\chi^{2}$ & $\mathrm{P}$ value \\
\hline \multicolumn{7}{|c|}{ Age (years) } \\
\hline$<60$ & 103 & 42.56 & 175 & 44.19 & & \\
\hline$\geq 60$ & 139 & 57.44 & 221 & 55.81 & 0.16 & 0.69 \\
\hline \multicolumn{7}{|l|}{ Gender } \\
\hline Male & 163 & 67.36 & 256 & 64.65 & & \\
\hline Female & 79 & 32.64 & 140 & 35.35 & 0.49 & 0.48 \\
\hline \multicolumn{7}{|c|}{ Smoking status } \\
\hline No & 103 & 42.56 & 204 & 51.52 & & \\
\hline Yes & 139 & 57.44 & 192 & 48.48 & 4.82 & 0.03 \\
\hline \multicolumn{7}{|c|}{ Drinking status } \\
\hline No & 104 & 42.98 & 153 & 38.64 & & \\
\hline Yes & 138 & 57.02 & 243 & 61.36 & 1.18 & 0.28 \\
\hline \multicolumn{7}{|c|}{ Family history of cancer } \\
\hline No & 217 & 89.67 & 377 & 95.20 & & \\
\hline Yes & 25 & 10.33 & 19 & 4.80 & 7.16 & 0.01 \\
\hline \multicolumn{7}{|c|}{ Intake of pickled food } \\
\hline No & 197 & 81.40 & 339 & 85.61 & & \\
\hline Yes & 45 & 18.60 & 57 & 14.39 & 1.97 & 0.16 \\
\hline
\end{tabular}

The genotypic distributions of GSTM1, GSTT1, and GSTP1 are listed in Table 2. The genotypic distributions of Ile/Ile, Ile/Val, and Val/Val in the GSTP1 gene were significantly different between the two groups $\left(\chi^{2}=21.04, \mathrm{P}<0.001\right)$. However, we did not find any differences in the genotype frequencies of GSTM1 $\left(\chi^{2}=1.01, \mathrm{P}=0.32\right)$ and GSTT1 $\left(\chi^{2}=0.73\right.$, $\mathrm{P}=0.39)$ between patients and controls. The genotypic distributions of GSTP1 were in line with HWE in patients $\left(\chi^{2}=1.28, \mathrm{P}=0.26\right)$ and controls $\left(\chi^{2}=3.02, \mathrm{P}=0.08\right)$.

Logistic regression analysis was performed to assess the association between GSTM1, GSTT1, and GSTP1 polymorphisms and risk of gastric cancer (Table 3). We observed that the Val/Val genotype of GSTP1 was associated with an increased risk of gastric cancer when compared with the Ile/Ile genotype $(\mathrm{OR}=3.19,95 \% \mathrm{CI}=1.84-5.56)$. Moreover, the Val allele of GSTP 1 showed higher association with risk of gastric cancer as compared with the Ile allele $(\mathrm{OR}=1.52,95 \% \mathrm{CI}=1.19-1.93)$. However, GSTM1 and GSTT1 polymorphisms did not seem to affect the gastric cancer development.

Genetics and Molecular Research 16 (1): gmr16018877 
Table 2. Genotypic distributions of GSTM1, GSTT1, and GSTP1

\begin{tabular}{l|c|c|c|c|c|c|c|c|c|c}
\hline Genotype & Patients & $\%$ & Controls & $\%$ & $\chi^{2}$ & P value & $\chi^{2}$ (HWE) & P value & $\chi^{2}($ HWE) & P value \\
\hline GSTM1 & & & & & & & & \multicolumn{2}{|c}{ In patients } \\
\hline Present & 132 & 54.55 & 232 & 58.59 & & & & & \\
\hline Null & 110 & 45.45 & 164 & 41.41 & 1.01 & 0.32 & & & \\
\hline GSTT1 & & & & & & & & & \\
\hline Present & 101 & 41.74 & 179 & 45.20 & & & & & \\
\hline Null & 141 & 58.26 & 217 & 54.80 & 0.73 & 0.39 & & & \\
\hline GSTP1 & & & & & & & & & & \\
\hline Ile/Ile & 83 & 34.30 & 169 & 42.68 & & & & & \\
\hline Ile/Val & 110 & 45.45 & 191 & 48.23 & & & & & & \\
\hline Val/Val & 49 & 20.25 & 36 & 9.09 & 21.04 & $<0.001$ & 1.28 & & \\
\hline
\end{tabular}

Table 3. Association between GSTM1, GSTT1, and GSTP1 polymorphisms and gastric cancer risk.

\begin{tabular}{|c|c|c|c|c|c|c|}
\hline Genotypes & Patients & $\%$ & Controls & $\%$ & OR $(95 \% \mathrm{CI})^{1}$ & $\mathrm{P}$ value \\
\hline \multicolumn{7}{|l|}{ GSTMI } \\
\hline Present & 132 & 54.55 & 232 & 58.59 & 1.0 (Reference) & - \\
\hline Null & 110 & 45.45 & 164 & 41.41 & $1.18(0.84-1.65)$ & 0.32 \\
\hline \multicolumn{7}{|l|}{ GSTT1 } \\
\hline Present & 101 & 41.74 & 179 & 45.20 & 1.0 (Reference) & - \\
\hline Null & 141 & 58.26 & 217 & 54.80 & $1.15(0.82-1.61)$ & 0.39 \\
\hline \multicolumn{7}{|l|}{ GSTP1 } \\
\hline Ile/Ile & 81 & 33.47 & 169 & 42.68 & 1.0 (Reference) & - \\
\hline Ile/Val & 112 & 46.28 & 195 & 49.24 & $1.20(0.83-1.73)$ & 0.31 \\
\hline $\mathrm{Val} / \mathrm{Val}$ & 49 & 20.25 & 32 & 8.08 & $3.19(1.84-5.56)$ & $<0.001$ \\
\hline \multicolumn{7}{|l|}{ Allele } \\
\hline Ile & 276 & 57.02 & 529 & 66.79 & 1.0 (Reference) & - \\
\hline Val & 208 & 42.98 & 263 & 33.21 & $1.52(1.19-1.93)$ & $<0.001$ \\
\hline
\end{tabular}

${ }^{1}$ Adjusted for gender, age, smoking status, and family history of cancer.

Spearman correlation analysis for the interaction between GSTP1 polymorphism and environmental factors is shown in Table 4 . We observed a significant interaction between smoking and GSTP1 polymorphism (Correlation coefficient $=0.253, \mathrm{P}<0.001$ ).

Table 4. Interaction between GSTP1 polymorphism and environmental factors in gastric cancer risk.

\begin{tabular}{l|c|c}
\hline & Correlation coefficient & P value \\
\hline Smoking status & 0.253 & $<0.001$ \\
\hline Drinking status & 0.068 & 0.31 \\
\hline Family history of cancer & 0.094 & 0.17 \\
\hline Intake of pickled food & 0.055 & 0.38 \\
\hline
\end{tabular}

\section{DISCUSSION}

In the current study, we found that the GSTP1 Val/Val genotype was associated with the development of gastric cancer, and that GSTP1 polymorphism may interact with tobacco smoking in defining gastric cancer susceptibility.

GSTs catalyze the reaction between glutathione and electrophilic compounds, thereby increasing their water solubility to facilitate their excretion from the body. GSTs form the main detoxification system for resistance to cell damage. Polymorphisms in GSTs could alter the detoxification process, which leads to accumulation of carcinogen precursors. As a result, these can activate or convert to toxic substances, and increase susceptibility to tumors (Morsi et al., 2006; Satoh et al., 2008). 
Polymorphisms in GSTP1 could lead to reduction in enzyme activity, and are therefore associated with development of malignant tumors. Previous studies have indicated that GSTP 1 polymorphism is associated with various kinds of cancers, such as acute myeloid leukemia, lung cancer, breast cancer, colorectal cancer, brain tumor, and esophageal cancer (Cong et al., 2014; Silva et al., 2014; Song et al., 2014; Jaramillo-Rangel et al., 2015; Nasr et al., 2015; Sharma et al., 2015; Soto-Quintana et al., 2015; Zhou et al., 2015; Geng et al., 2016; Khabaz et al., 2016; Kimi et al., 2016). Several studies have also reported that GSTP1 polymorphism is associated with risk of gastric cancer in various populations, but the results were inconsistent (Nguyen et al., 2010; Zhang et al., 2011; Bao et al., 2012; GarcíaGonzález et al., 2012; Jing et al., 2012; Zhang et al., 2012; Ma et al., 2013). Four studies were carried out in a Chinese population, and significant associations were found between GSTP1 Ile105Val polymorphism and risk of gastric cancer (Bao et al., 2012; Zhang et al., 2012; Ma et al., 2013). However, several studies conducted in American, Turkish, southEuropean, Vietnamese, as well as Chinese populations have indicated that GSTP1 Ile105Val polymorphism did not play a role in the development of gastric cancer (Nguyen et al., 2010; Zhang et al., 2011; García-González et al., 2012; Jing et al., 2012). In our study, we found a significant association between GSTP1 Ile105Val polymorphism and development of gastric cancer in a Chinese population. Discrepancies between the results of our studies and that of the previous studies may be attributed to differences in ethnicities and selection of subjects, as well as disease stages and sample sizes.

Moreover, we found significant interactions between GSTP1 Ile105Val polymorphism and tobacco smoking in risk of gastric cancer. Tobacco smoking could promote the expression of nuclear hypoxia-inducible factor-1a in humans, and the synergistic effects of tobacco smoking and GSTP1 Ile105Val polymorphism could promote the pathogenesis of gastric cancer (Huang et al., 2012). One limitation should be considered in this study. The gastric cancer patients and control subjects were selected from only one hospital, and may not be sufficiently representative of other populations.

In conclusion, our study indicated that GSTP1 Ile105Val polymorphism might be associated with risk of gastric cancer. In addition, GSTP1 Ile105Val polymorphism may also interact with tobacco smoking to further increase risk of gastric cancer.

\section{Conflicts of interest}

The authors declare no conflict of interest.

\section{ACKNOWLEDGMENTS}

Research supported by the Guangdong Provincial Department of Science and Technology (\#2012B010900038) and the Guangzhou Science and Technology Planning Project (\#1561000217).

\section{REFERENCES}

Bao LD, Niu JX, Song H, Wang Y, et al. (2012). Association between the GSTP1 codon 105 polymorphism and gastric cancer risk: an updated meta-analysis. Asian Pac. J. Cancer Prev. 13: 3687-3693. http://dx.doi.org/10.7314/ APJCP.2012.13.8.3687

Genetics and Molecular Research 16 (1): gmr16018877 
Broekman MM, Bos C, Te Morsche RH, Hoentjen F, et al. (2014). GST Theta null genotype is associated with an increased risk for ulcerative colitis: a case-control study and meta-analysis of GST Mu and GST Theta polymorphisms in inflammatory bowel disease. J. Hum. Genet. 59: 575-580. http://dx.doi.org/10.1038/jhg.2014.77

Cong N, Liu L, Xie Y, Shao W, et al. (2014). Association between glutathione S-transferase T1, M1, and P1 genotypes and the risk of colorectal cancer. J. Korean Med. Sci. 29: 1488-1492. http://dx.doi.org/10.3346/jkms.2014.29.11.1488

den Hoed CM and Kuipers EJ (2016). Gastric cancer: How can we reduce the incidence of this disease? Curr. Gastroenterol. Rep. 18: 34. http://dx.doi.org/10.1007/s11894-016-0506-0

Farlay J, Soerjomataram I, Ervik M, Dikshit R, et al. (2013). GLOBOCAN 2012 v1.0, Cancer incidence and mortality worldwide: IARC CancerBase No. 11 [internet]. Lyon, France: International Agency for Research on Cancer. Available at [http://globocan.iarc.fr]. Accessed May 5, 2016.

García-González MA, Quintero E, Bujanda L, Nicolás D, et al. (2012). Relevance of GSTM1, GSTT1, and GSTP1 gene polymorphisms to gastric cancer susceptibility and phenotype. Mutagenesis 27: 771-777. http://dx.doi.org/10.1093/ mutage/ges049

Geng P, Li J, Wang N, Ou J, et al. (2016). Genetic contribution of polymorphisms in glutathione StTransferases to brain tumor risk. Mol. Neurobiol. 53: 1730-1740. http://dx.doi.org/10.1007/s12035-015-9097-2

Guven M, Unal S, Erhan D, Ozdemir N, et al. (2015). Role of glutathione S-transferase M1, T1 and P1 gene polymorphisms in childhood acute lymphoblastic leukemia susceptibility in a Turkish population. Meta Gene 5: 115-119. http:// dx.doi.org/10.1016/j.mgene.2015.06.002

Hidaka A, Sasazuki S, Matsuo K, Ito H, et al.; JPHC Study Group (2016). CYP1A1, GSTM1 and GSTT1 genetic polymorphisms and gastric cancer risk among Japanese: A nested case-control study within a large-scale populationbased prospective study. Int. J. Cancer 139: 759-768. http://dx.doi.org/10.1002/ijc.30130

Huang B, Liu B, Yang L, Li Y, et al. (2012). Functional genetic variants of c-Jun and their interaction with smoking and drinking increase the susceptibility to lung cancer in southern and eastern Chinese. Int. J. Cancer 131: E744-E758. http://dx.doi.org/10.1002/ijc.27407

Jaramillo-Rangel G, Ortega-Martínez M, Cerda-Flores RM and Barrera-Saldaña HA (2015). Polymorphisms in GSTM1, GSTT1, GSTP1, and GSTM3 genes and breast cancer risk in northeastern Mexico. Genet. Mol. Res. 14: 6465-6471. http://dx.doi.org/10.4238/2015.June.11.22

Jing C, Huang ZJ, Duan YQ, Wang PH, et al. (2012). Glulathione-S-transferases gene polymorphism in prediction of gastric cancer risk by smoking and Helicobacter pylori infection status. Asian Pac. J. Cancer Prev. 13: 3325-3328. http://dx.doi.org/10.7314/APJCP.2012.13.7.3325

Khabaz MN, Al-Maghrabi JA, Nedjadi T, Gar MA, et al. (2016). Does Val/Val genotype of GSTP1 enzyme affects susceptibility to colorectal cancer in Saudi Arabia? Neuroendocrinol. Lett. 37: 46-52.

Khayatzadeh S, Feizi A, Saneei P and Esmaillzadeh A (2015). Vitamin D intake, serum Vitamin D levels, and risk of gastric cancer: A systematic review and meta-analysis. J. Res. Med. Sci. 20: 790-796.http://dx.doi.org/10.4103/1735$\underline{1995.168404}$

Kimi L, Ghatak S, Yadav RP, Chhuani L, et al. (2016). Relevance of GSTM1, GSTT1 and GSTP1 gene polymorphism to breast cancer susceptibility in Mizoram population, northeast India. Biochem. Genet. 54: 41-49. http://dx.doi. org/10.1007/s10528-015-9698-5

Lee YC, Chiang TH, Chou CK, Tu YK, et al. (2016). Association between Helicobacter pylori eradication and gastric cancer incidence: a systematic review and meta-analysis. Gastroenterology 150: 1113-1124.e5. http://dx.doi. org/10.1053/j.gastro.2016.01.028

Li XF, Shen M, Cai JW, Zeng YQ, et al. (2015). Association of interleukin-17 gene polymorphisms and Helicobacter pylori infection with gastric cancer susceptibility: a cumulative and comprehensive meta-analysis. Int. J. Clin. Exp. Med. 8: 17623-17633.

Lin X, Hu D, Chen G, Shi Y, et al. (2016). Associations of THBS2 and THBS4 polymorphisms to gastric cancer in a Southeast Chinese population. Cancer Genet. 209: 215-222.http://dx.doi.org/10.1016/j.cancergen.2016.04.003

Ma Y, Wei X, Han G, Xue M, et al. (2013). Glutathione S-transferase P1 Ile105Val polymorphism contributes to increased risk of gastric cancer in East Asians. Tumour Biol. 34: 1737-1742. http://dx.doi.org/10.1007/s13277-013-0711-5

Morsi MI, Hussein AE, Mostafa M, El-Abd E, et al. (2006). Evaluation of tumour necrosis factor-alpha, soluble P-selectin, gamma-glutamyl transferase, glutathione S-transferase-pi and alpha-fetoprotein in patients with hepatocellular carcinoma before and during chemotherapy. Br. J. Biomed. Sci. 63: 74-78. http://dx.doi.org/10.1080/09674845.20 06.11732724

Nasr AS, Sami RM, Ibrahim NY and Darwish DO (2015). Glutathione S transferase (GSTP 1, GSTM 1, and GSTT 1) gene polymorphisms in Egyptian patients with acute myeloid leukemia. Indian J. Cancer 52: 490-495. http://dx.doi. org/10.4103/0019-509X.178408

Genetics and Molecular Research 16 (1): gmr16018877 
Nguyen TV, Janssen MJ, van Oijen MG, Bergevoet SM, et al. (2010). Genetic polymorphisms in GSTA1, GSTP1, GSTT1, and GSTM1 and gastric cancer risk in a Vietnamese population. Oncol. Res. 18: 349-355. http://dx.doi.org/10.3727 1096504010X12626118080064

Okada R, Naito M, Hattori Y, Seiki T, et al.; Japan Multi-institutional Collaborative Cohort Study Group (2016). Matrix metalloproteinase 9 gene polymorphisms are associated with a multiple family history of gastric cancer. Gastric Cancer.http://dx.doi.org/10.1007/s10120-016-0608-2

Qiu LX, Cheng L, He J, Zhou ZR, et al. (2016). PSCA polymorphisms and gastric cancer susceptibility in an eastern Chinese population. Oncotarget 7: 9420-9428.

Rao DK, Shaik NA, Imran A, Murthy DK, et al. (2014). Variations in the GST activity are associated with single and combinations of GST genotypes in both male and female diabetic patients. Mol. Biol. Rep. 41: 841-848. http://dx.doi. org/10.1007/s11033-013-2924-5

Satoh K, Yamakawa D, Sugio H, Kida K, et al. (2008). Bile duct-bound growth of precursor cells of preneoplastic foci inducible in the initiation stage of rat chemical hepatocarcinogenesis by 2-acetylaminofluorene. Jpn. J. Clin. Oncol. 38: 604-610. http://dx.doi.org/10.1093/jjco/hyn080

Sharma N, Singh A, Singh N, Behera D, et al. (2015). Genetic polymorphisms in GSTM1, GSTT1 and GSTP1 genes and risk of lung cancer in a North Indian population. Cancer Epidemiol. 39: 947-955. http://dx.doi.org/10.1016/j. canep.2015.10.014

Shi J, Liu Y, Liu J and Zhou J (2015). Hsa-miR-449a genetic variant is associated with risk of gastric cancer in a Chinese population. Int. J. Clin. Exp. Pathol. 8: 13387-13392.

Silva TM, Marques CR, Marques Filho MF, Marques AB, et al. (2014). Association of the GSTT1 polymorphism in upper aerodigestive tract cancer with tobacco smoking. Genet. Mol. Res. 13: 528-537. http://dx.doi.org/10.4238/2014. January.21.22

Song Y, Du Y, Zhou Q, Ma J, et al. (2014). Association of GSTP1 Ile105Val polymorphism with risk of esophageal cancer: a meta-analysis of 21 case-control studies. Int. J. Clin. Exp. Med. 7: 3215-3224.

Soto-Quintana O, Zúñiga-González GM, Ramírez-Patiño R, Ramos-Silva A, et al. (2015). Association of the GSTM1 null polymorphism with breast cancer in a Mexican population. Genet. Mol. Res. 14: 13066-13075. http://dx.doi. org/10.4238/2015.October.26.2

Tripathi S, GhoshalU, GhoshalUC, Mittal B, etal.(2008). Gastric carcinogenesis: Possible role of polymorphisms of GSTM1, GSTT1, and GSTP1 genes. Scand. J. Gastroenterol. 43: 431-439.http://dx.doi.org/10.1080/00365520701742930

Xia ZG, Yin HF, Long Y, Cheng L, et al. (2016). Genetic variant of miR-146a rs2910164 C > G and gastric cancer susceptibility. Oncotarget [In press].

Yadav DS, Devi TR, Ihsan R, Mishra AK, et al. (2010). Polymorphisms of glutathione-S-transferase genes and the risk of aerodigestive tract cancers in the Northeast Indian population. Genet. Test. Mol. Biomarkers 14: 715-723. http:// dx.doi.org $/ 10.1089 / \mathrm{gtmb} .2010 .0087$

Zhang AP, Liu BH, Wang L, Gao Y, et al. (2011). Glutathione S-transferase gene polymorphisms and risk of gastric cancer in a Chinese population. Asian Pac. J. Cancer Prev. 12: 3421-3425.

Zhang RG, Duan GC, Fan QT and Chen SY (2016). Role of Helicobacter pylori infection in pathogenesis of gastric carcinoma. World J. Gastrointest. Pathophysiol. 7: 97-107. http://dx.doi.org/10.4291/wjgp.v7.i1.97

Zhang Y, Sun LP, Xing CZ, Xu Q, et al. (2012). Interaction between GSTP1 Val allele and H. pylori infection, smoking and alcohol consumption and risk of gastric cancer among the Chinese population. PLoS One 7: e47178. http://dx.doi. org/10.1371/journal.pone.0047178

Zhang Y, Zeng X, Lu H, Li Y, et al. (2015). Association between Interleukin-8-251A/T polymorphism and gastric cancer susceptibility: a meta-analysis based on 5286 cases and 8000 controls. Int. J. Clin. Exp. Med. 8: 22393-22402.

Zhou CF, Ma T, Zhou DC, Shen T, et al. (2015). Association of glutathione S-transferase pi (GSTP1) Ile105Val polymorphism with the risk of skin cancer: a meta-analysis. Arch. Dermatol. Res. 307: 505-513. http://dx.doi. org/10.1007/s00403-015-1576-9

Genetics and Molecular Research 16 (1): gmr16018877 